\title{
Signaling pathways involved in apoptosis induced by novel angucycline antibiotic landomycin $E$ in Jurkat T-leukemia cells
}

\author{
R. R. Panchuk \\ Institute of Cell Biology NAS of Ukraine \\ 14/16, Drahomanov St., Lviv, Ukraine, 79005 \\ rpanchuk@ukr.net
}

\begin{abstract}
Aim. To study the molecular mechanisms of action of novel anticancer antibiotic landomycin E (LE). Methods. Annexin V/propidium iodide, DAPI (4',6-diamidino-2-phenylindole) staining, Western-blot analysis. Results. LE applied in $2 \mu \mathrm{g} / \mathrm{ml}$ dose $\left(I C_{50}\right)$, induced reactive oxygen species (ROS)-dependent splitting of poly [ADP-ribose] polymerase 1 (PARP-1) and DNA Fragmentation Factor 45 (DFF45) proteins involved in DNA reparation. This effect was observed $6 \mathrm{~h}$ after the start of treatment and it positively correlated with phosphatidyl serine externalization (early morphological marker of apoptosis). We suggest that cleavage of PARP-1 and DFF45 was mediated by active caspase-7 which is a key effector caspase in the LE-induced apoptosis in leukemia cells. We found that activation of initiator procaspase-10 (involved in receptormediated apoptosis) was the earliest detected event in LE-induced apoptotic signaling pathways; however, this activation was shown to be ROS-independent. We also demonstrated that the induction of apoptosis by $L E$ is accompanied by activation of apoptosis-inducing factor (AIF) in mitochondria. Conclusions. Our data suggest that LE-induced cascade of apoptotic events is started by the initiator caspase-10 which leads to activation of the effector caspase-7 and AIF that is known to induce caspase-independent apoptosis involving ROS generation.
\end{abstract}

Keywords: tumor cells, landomycin E, apoptosis, caspases, AIF, reactive oxygen species.

Introduction. Streptomyces species play a significant role in the production of bioactive natural products, many of which are polyketides, such as anthracyclines and tetracylines [1]. The angucyclines are the largest group of polycyclic aromatic polyketides with more than 120 members that is constantly growing $[2,3]$. The most characteristic feature of angucyclines is their uniquely shaped benz[a]anthracene tetracyclic framework with an angularly condensed ring [4]. The group is rich in chemical scaffolds and various biological ac-

(c) Institute of Molecular Biology and Genetics NAS of Ukraine, 2011 tivities, predominantly antitumor and antibacterial. Yet, none of these compounds have been developed to clinically applied drugs usually due to toxicity or solubility issues [1-3]. Landomycins are the most perspective group of angucyclines possessing strong antineoplastic potential.

All natural landomycins identified to date share the same aglycon (landomycinone) and vary only in their oligosaccharide chain, a linear glycosidic chain containing only di- and trideoxysugars ( $\beta$-D-olivose and $\alpha$-L-rhodinose) [5]. They show broad activity against many cancer cell lines with the general tendency that 
compounds with longer saccharide chains show higher activity $[6,7]$.

The main compound, landomycin A, containing a hexasaccharide side chain, has so far been shown to be the most potent congener and was extensively tested by the National Cancer Institute (USA) towards 60 selected human cancer cell line panel and particularly towards prostate cancer lines $[8,9]$.

Landomycin E (LE) is a novel representative of landomycins synthesized by Streptomyces globisporus strain 1912 growing in a soybean culture medium [10]. It contains 3 saccharide residues ( $\alpha$-L-rhodinose- $(1 \rightarrow$ $\rightarrow 3)-\beta$-D-olivose-( $1 \rightarrow 4)-\beta$-D-olivose) conjugated to an angular tetracyclic quinone. Antitumor action of LE was demonstrated against various tumor cell lines in vitro [11] and Guerin carcinoma in rats in vivo [12]. It was also reported that LE is able to overcome resistance to doxorubicin, vincristin and colchicine in cancer cells, overexpressing various types of ABC-transporters (P-gp, MRP-1, bcrp) [13, 14]. However, molecular mechanisms of its antineoplastic effects still require clarification.

Flow cytometry experiments showed that landomycin A specifically blocked cell cycle progression from G1 phase to S phase (DNA synthesis) [8]. Structurally unrelated anticancer drugs (e. g. bleomycin, mitomycin $\mathrm{C}$, and neocarzinostatin) possess a similar pattern of cell cycle inhibition. However, in contrast to many clinically useful drugs of a similar structure, like the anthracyclines and chromomycins, landomycins do not bind directly to DNA $[4,13,14]$. Landomycin E whose glycosidic chain contains only 3 deoxysugars, does not possess cell cycle specificity [14], but it strongly impairs mitochondria functions leading to the generation of reactive oxygen species (ROS). Nevertheless, role of mitochondria and ROS in LE-mediated apoptosis remains poorly understood. It needs to be explained whether the LE-induced early generation of ROS in mitochondria can trigger caspase activation, or it is only a supplementary step in general scheme of apoptosis induced by this drug.

The main goal of present study was to investigate in more detail specific apoptotic signaling pathways which are induced by the landomycin $\mathrm{E}$ in leukemia cells. This might allow to identify potential molecular targets of LE action in tumor cells.
Materials and methods. Landomycin E (95\% purity, according to TLC data) was prepared in the laboratory of Dr. B. Matselyukh at D. K. Zabolotny Institute of Microbiology and Virology, National Academy of Sciences of Ukraine. Doxorubicin produced by «Ebeve» (Austria) was bought at the local pharmacy.

Human Jurkat T-leukemia cells were obtained from cell culture collections at R. E. Kavetsky Institute of Experimental Pathology, Oncology and Radiobiology, National Academy of Sciences of Ukraine. Cells were cultured in RPMI 1640 medium supplemented with $10 \%$ fetal calf serum («Sigma Chemical Co.», USA), $50 \mu \mathrm{g} / \mathrm{ml}$ streptomycin («Sigma Chemical Co.»), 50 units $/ \mathrm{ml}$ penicillin («Sigma Chemical Co.») in $5 \% \mathrm{CO}_{2}$-containing humidified atmosphere at $37^{\circ} \mathrm{C}$.

For experiments, cells were seeded into 24-well tissue culture plates («Greiner Bio-one», Germany). The cytotoxic effect of antitumor drugs was studied under the inverted microscope («Biolam-P1», «LOMO», Russian Federation) after cell staining with trypan blue dye $(0.1 \%)$. N-acetylcysteine («Sigma», USA) was dissolved in $1 \times$ phosphate buffered saline (PBS) and added to cell culture $30 \mathrm{~min}$ before addition of anticancer drugs (final concentration $1 \mathrm{mM}$ ). Broad caspase inhibitor z-VAD-fmk («BD Pharmingen», USA), $20 \mathrm{mM}$ stock solution in DMSO was dissolved in cell culture medium prior to addition to cell culture to achieve final concentration $100 \mu \mathrm{M}$.

FITC-conjugated annexin V («BD Pharmingen», USA) and propidum iodide («Sigma») double staining was performed to detect early apoptotic events under treatment of Jurkat cels by LE. At 1, 3, 6, 12, $24 \mathrm{~h}$ after addition of LE Jurkat cells were centrifuged at 2000 $\mathrm{rpm}$, washed twice with $1 \times \mathrm{PBS}$, and incubated for 15 min in annexin V binding buffer («BD Pharmingen») containing 1/20 volume of FITC-conjugated annexin $\mathrm{V}$ solution and PI $(20 \mu \mathrm{g} / \mathrm{ml}) .10 \mu 1$ of cell suspension was placed on slides.

Cytomorphological investigations were performed using Zeiss AxioImager A1 fluorescent microscope («Zeiss», Germany).

DAPI staining was performed to study chromatin condensation in Jurkat cells at various timepoints of LE treatment. 1, 3, 6, 12, and $24 \mathrm{~h}$ after the addition of LE, Jurkat cells were centrifuged at 2,000 rpm, washed twice with $1 \times \mathrm{PBS}$, fixed in $4 \%$ paraformaldehyde so- 
lution for $15 \mathrm{~min}$ at room temperature, and then permeabilized by $0.1 \%$ Triton X-100 solution in PBS for 3 $\min$. After that, cells were incubated with $1 \mu \mathrm{g} / \mathrm{ml}$ DAPI solution (4',6-diamidino-2-phenylindole) («Sigma») for $5 \mathrm{~min}$, washed twice with PBS, $10 \mu \mathrm{l}$ of cell suspension was added to slides and cover glasses placed. Cytomorphological investigations were performed on Zeiss AxioImager A1 fluorescent microscope.

Western blot analysis was used to evaluate expression of proteins, involved in signaling pathways of apoptosis, induced by landomycin E, and performed, as described before [15]. Membrane was incubated with monoclonal rabbit antibodies raised against cleaved caspase-3, cleaved caspase-6, cleaved caspase-7, Bid («Cell Signaling», USA), AIF (sc-5586), Bax (sc6236), Bcl-2 (sc-492), Bcl- $\mathrm{X}_{\mathrm{L} / \mathrm{S}}$ (sc-634) («Santa Cruz Biotech», USA), caspase-9 (BD 556585) («BD Pharmingen»), $\beta$-actin («Sigma»), monoclonal goat antibodies against procaspase-3 (sc-1226) («Santa Cruz Biotech») and monoclonal mouse antibodies against caspase-2, caspase-8 («BD Pharmingen»), caspase-10 («MBL», USA) for $12 \mathrm{~h}$ at $4{ }^{\circ} \mathrm{C}$ at slow shaking. Dilution of primary antibodies was 1:1,000 in 5\% BSA, $0.1 \%$ PBS-Tween, except the antibodies against $\beta$-actin diluted (1:5000) as recommended by supplier.

Results and discussion. LE was shown to be highly active for all studied tumor cell lines of both epithelial and mesenchymal origin, and its effect was comparable with that of doxorubicin and vincristin. Leukemia cells were most sensitive to LE action [11]. That is why we used human T-leukemia Jurkat cells in our further studies.

Phosphatidylserine translocation to the external layer of the cell membrane of dying cells measured by annexin $\mathrm{V}$ test is considered to be one of the earliest hallmarks of apoptosis [16]. Landomycin E (2 $\mu \mathrm{g} / \mathrm{ml})$ induced early phosphatidylserine translocation already at $6 \mathrm{~h}$ after treatment of Jurkat cells, while doxorubicin in the same concentration caused PS exposure only at $12 \mathrm{~h}$ after the treatment start (Fig. 1, $A$, see inset). Massive DNA fragmentation was measured by cytomorphological evaluation of apoptotic bodies and hypercondensed chromatine in Jurkat cells using DAPI staining. Such fragmentation has appeared only at $12 \mathrm{~h}$ both after LE and Dx treatment (Fig. 1, $B$, see inset). Thus, LE induces more rapid apoptosis, than Dx, in spi- te of LE's lower cytotoxic activity $[11,13,14]$. Doxorubicin is classified as a topoisomerase II poison [17], although other mechanisms of its action have been also proposed: ROS generation, DNA intercalation, inhibition of nucleic acid synthesis $[18,19]$. Thus, an induction of apoptosis by Dx can be explained by its DNAdamaging nature, while LE may use other pathways taking place more rapidly than at DNA damaging in p53dependent apoptosis.

Mitochondria are perfect candidate for LE targeting. ROS are overproduced by mitochondria under pathological conditions, such as ionizing radiation, heat shock or anticancer drug action [20]. ROS scavenger $\mathrm{N}$-acetylcysteine (NAC) was used to study in detail ROS involvement in LE and Dx apoptotic signaling in Jurkat cells.

Pre-treatment of Jurkat cells for 30 min with $1 \mathrm{mM}$ NAC restored number of live cells to control levels at 6 $\mathrm{h}$ and $12 \mathrm{~h}$ after LE treatment $(\mathrm{P}<0,01)$, while at $24 \mathrm{~h}$ no significant effect of NAC at $\mathrm{IC}_{50}$ concentration of LE $(2 \mu \mathrm{g} / \mathrm{ml})$ could be observed (Fig. 2). It is known, that Dx anticancer activity also involves ROS [18], but in our case, no statistically significant differences between Dx-treated and Dx + NAC-pre-treated cells were found (Fig. 2).

Caspase-dependent signaling pathways were studied by Western-blot analysis.

Activation of key effector caspases - caspase-3 which cleaves enzymes PARP-1 and DFF45, as well as activation of caspase- 6 which cleaves nuclear lamina, take place only at $24 \mathrm{~h}$ after LE treatment of Jurkat cells (Fig. 3). This was also confirmed by a study of expression of procaspase- 3 that was cleaved only at $24 \mathrm{~h}$, while at all time points from $1 \mathrm{~h}$ till $12 \mathrm{~h}$ no signs of its cleavage were detected. However, slight activation of other key effector caspase- 7 was observed already at $6 \mathrm{~h}$ after LE treatment of Jurkat cells, which perfectly correlated with time-dependent cleavage of PARP-1 and DFF45 (Fig. 3).

In contrast to LE, doxorubicin $(2 \mu \mathrm{g} / \mathrm{ml})$ induced simultaneous activation of effector caspases- 3 and -7 at $12 \mathrm{~h}$, while active form of effector caspase- 6 appeared only at $24 \mathrm{~h}$ after treatment (Fig. 4). We suggest that caspase-7 plays a key role in late stages of LE-induced apoptosis in leukemia cells, while caspase-3 and caspase- 6 are not so important. 

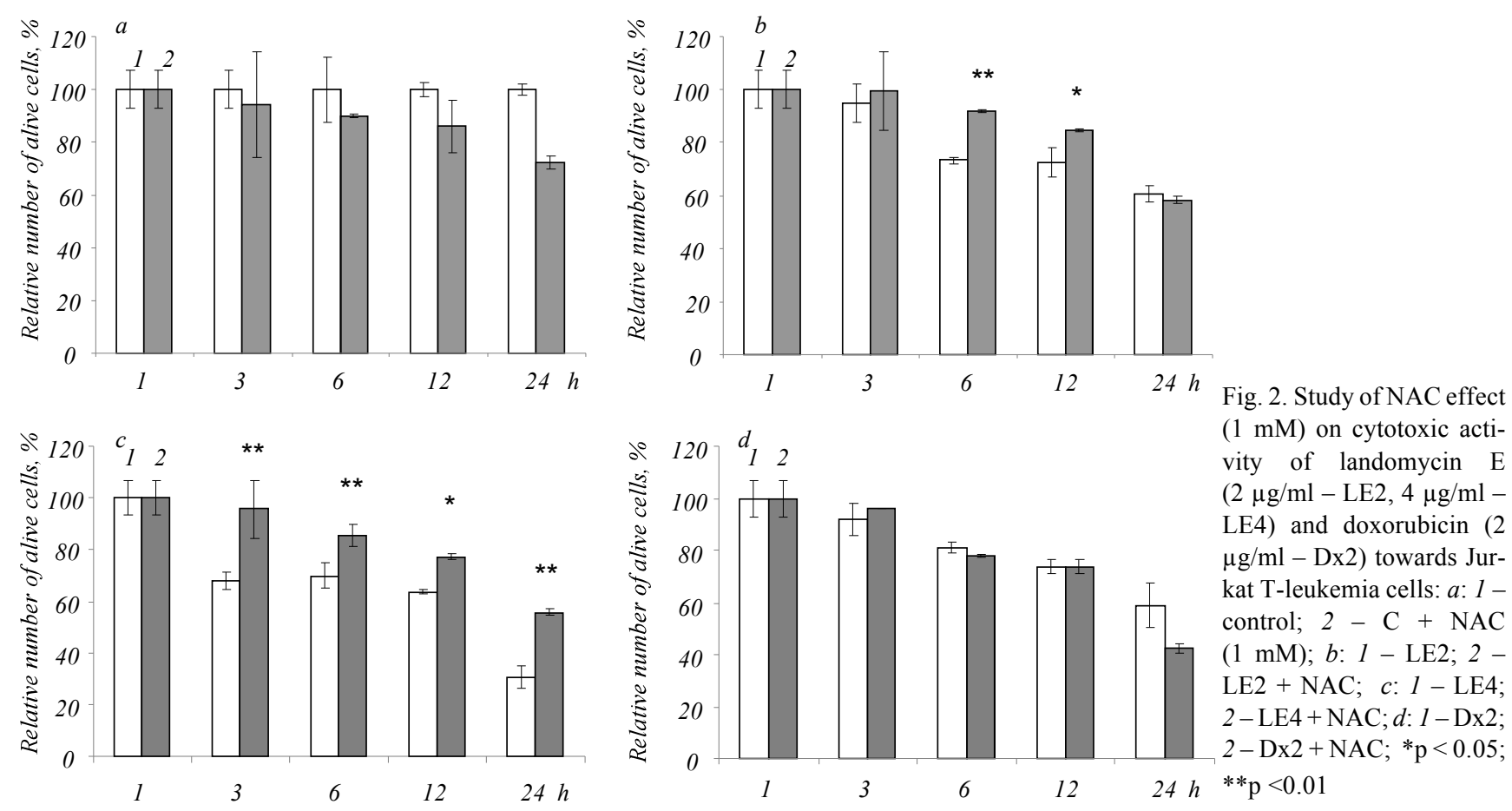

Pre-treatment of Jurkat cells with 1 mM NAC for 30 min led to inhibition of production of reactive oxygen species under LE treatment and also completely blocked activation of caspase- 7 and cleavage of DFF45 and PARP- 1 by this enzyme at $6,12 \mathrm{~h}$, and partly at $24 \mathrm{~h}$ (Fig. 3).

However, there were no significant changes in the levels of proapoptotic protein Bax involved in mitochondria-induced apoptosis (Fig. 5). Thus, one can see that ROS do not activate Bax and, thus, their role in LE-induced apoptosis is supplementary, but not initiative one. This can be also confirmed by absence of changes in expression of antiapoptotic proteins of Bcl-2 family - Bcl- $X_{\mathrm{L}}$ and Bcl-2 itself (Fig. 5), which clearly indicates that small mitochondrial proteins are not involved in LE-induced apoptosis. NAC pre-treatment also had no effect on their levels in target cells. Also in case of LE cleavage of caspase-9 (key initiator caspase, involved in mitochondria-mediated apoptosis) takes place only at $24 \mathrm{~h}$ after treatment (Fig. 5) and cytochrome $\mathrm{C}$ release from mitochondria - only at $12 \mathrm{~h}$ (data not shown), while effector caspase-7 was activated already at $6 \mathrm{~h}$ after LE treatment. This again indicates important, but not initiatory role of mitochondria in these processes.
That is why FAS/CD95 receptor in plasma membrane of cells can be another potential target for this drug [21]. Since all landomycins have linear glycosidic chain, they can interact in some way with extracellular part of CD95 receptor or cell glycocalyx and induce receptor-mediated apoptosis via caspase- 8 or caspase10. This suggestion can be indirectly supported by the results of National Cancer Institute testing of landomycin $\mathrm{A}$, landomycin $\mathrm{E}$ and landomycin $\mathrm{D}$, where landomycins with longer glycosidic chain had significantly higher antineoplastic activity (see www.dtp.nci.nih. gov). To study this hypothesis, Western-blot analysis was performed with antibodies against initiator caspases-2, $-8,-10$.

It was found that LE $(2 \mu \mathrm{g} / \mathrm{ml}, 24 \mathrm{~h})$ induced cleavage of all tested initiator caspases, but at early stages $(6 \mathrm{~h})$, caspase-10 was the only active enzyme, and its activation was not blocked by NAC (Fig. 5). Thus, caspase-10 is the only initiator enzyme, which is activated at earliest timepoint by LE, and its activation is not ROS-mediated. So, caspase-10 seems to act upstream of mitochondria in the LE-induced apoptosis.

Doxorubicin is also known to induce ROS production in target cells [18], but this effect was much weaker than that of LE (see Fig. 2). NAC pre-treatment 


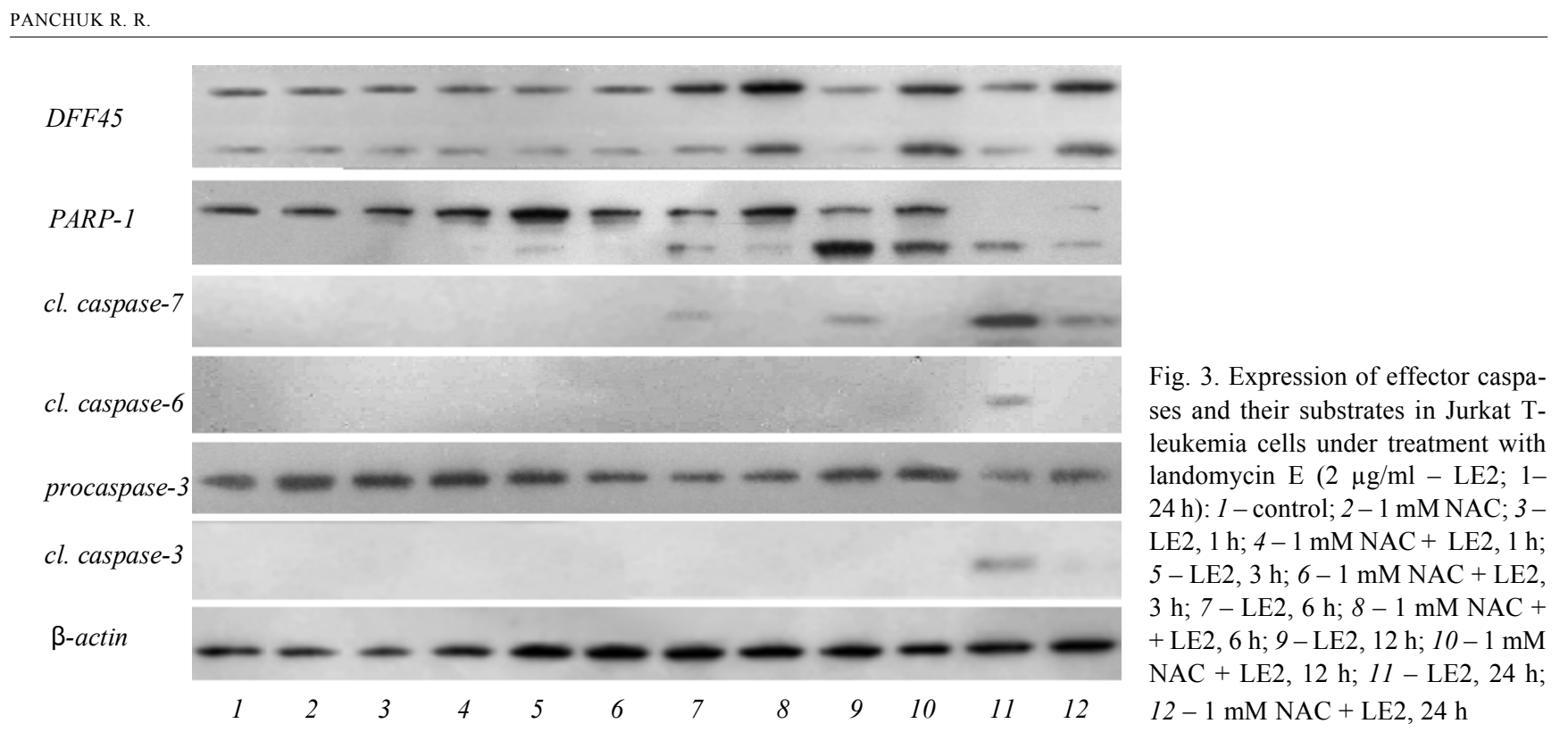

had no effect in diminishing cytotoxicity of Dx in vitro in Jurkat cells, but partly inhibited activation of effector caspases-3, -7 and their cleavage of PARP-1 and DFF45 at $12 \mathrm{~h}$ after Dx treatment of Jurkat cells (see Fig. 4). No effect of NAC was observed at $24 \mathrm{~h}$ timepoint, which indicates subsidiary role of ROS in Dxinduced apoptosis. It is known that Dx activates mitochondrial pathway of apoptosis via p53 protein or, when it is absent (as in case with Jurkat cells where p53 is inactivated) via cleavage of small mitochondrial Bid protein via caspase-8 [22], which was also observed in our case (Fig. 5). Landomycin E led to Bid cleavage only in $24 \mathrm{~h}$ which excludes caspase-8-Bid bridge in apoptosis induction. This suggests principal difference of the mechanisms of LE-induced cell death from Dxinduced ones.

Most anticancer drugs induce classical caspase-dependent apoptosis. However, several chemotherapeutic drugs of clinical use and some natural agents with anti-tumorigenic properties can also lead to caspase-independent type of cell death potentiated by specific «backup death pathways» [23]. Broad caspase inhibitor $\mathrm{z}-\mathrm{VAD}$-fmk was used to find out what death pathway is preferentially stimulated by LE in Jurkat cells. Pretreatment of Jurkat cells for $1 \mathrm{~h}$ with $100 \mu \mathrm{M}$ of z-VADfmk attenuated Dx-induced $(2 \mu \mathrm{g} / \mathrm{ml})$ apoptosis for 24 $\mathrm{h}$, but failed to stop LE-induced $(2 \mu \mathrm{g} / \mathrm{ml})$ apoptosis measured by counting annexin V +/PI-cells (Fig. 6).

Apoptosis-inducing factor (AIF) whose level was significantly increased during LE-induced apoptosis
(Fig. 5), can be another candidate for key apoptotic mediator.

AIF was the first mitochondrial protein shown to mediate caspase-independent cell death [24]. It was initially characterized as a protein confined within the mitochondrial intermembrane space of healthy cells. During apoptosis AIF is released from mitochondria and translocates to the nucleus, where it mediates nuclear features of apoptosis such as chromatin condensation and large-scale ( $\sim 50 \mathrm{~kb})$ DNA degradation [25]. In healthy cells, AIF plays role in oxidative phosphorylation and redox control [26]. Thus, AIF can generate ROS playing role downstream in the LE-induced signaling apoptotic pathways. We found a significant increase in AIF level in Jurkat cells treated with LE (Fig. 4), which confirms our suggestion of its role in LE action.

Thus, it is AIF, but not caspase-7, which seems to play a major role at terminal stages of LE-induced apoptosis. This might explain why NAC, even used for $24 \mathrm{~h}$, does not stop death of LE-treated cells. NAC can block activation of effector caspases, but not of AIF, which itself is a source of ROS, and thus NAC pretreatment cannot stop AIF's proapoptotic action.

In conclusion, despite similar chemical structure, doxorubicin and landomycin E use different signaling pathways inducing apoptosis. Dx-induced apoptosis takes place later than LE-induced one, and its first signs are observed only at $12 \mathrm{~h}$ after Dx treatment of Jurkat cells. Dx induces apoptosis via DNA damage and mito- 


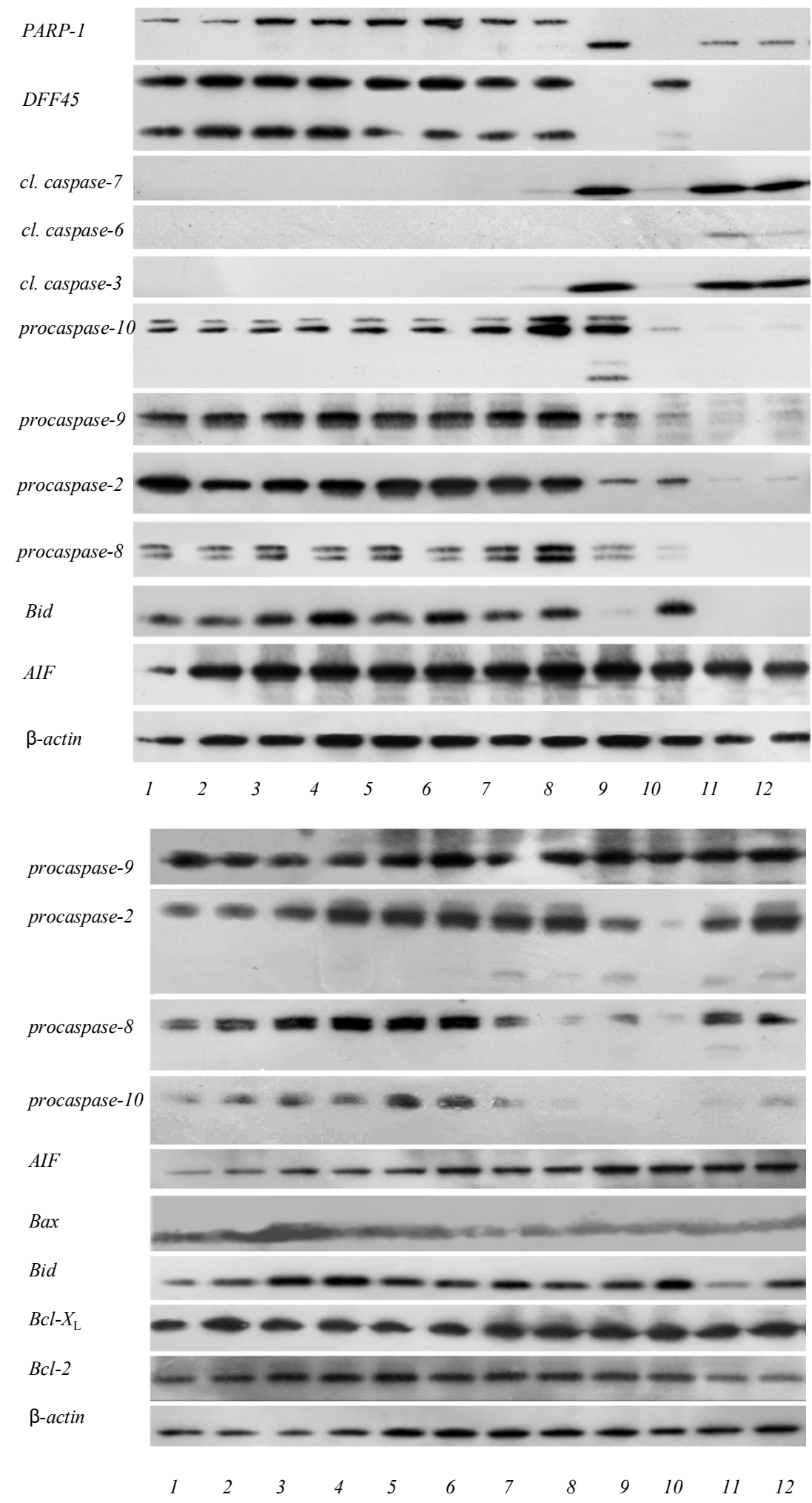

Fig. 4. Expression of proapoptotic proteins involved in early and late stages of apoptosis in Jurkat T-leukemia cells under treatment with doxorubicin $(2 \mu \mathrm{g} / \mathrm{ml}, 1-24 \mathrm{~h})$. See legend to Fig. 3, drug doxorubicin

Fig. 5. Expression of initiator caspases and proapoptotic proteins involved in early stages of apoptosis in Jurkat T-leukemia cells under treatment with landomycin E (2 $\mu \mathrm{g} / \mathrm{ml}, 1-24 \mathrm{~h})$. See legend to Fig. 3

chondrial pathway, confirmed by cleavage of initiator procaspase- 8 , its substrate Bid and procaspase-9 leading to subsequent downstream activation of effector members of caspase cascade. In contrast to Dx, LE may use CD95 receptor to activate cleavage of caspase-10 that occurs $6 \mathrm{~h}$ after LE treatment and is ROS-in- 


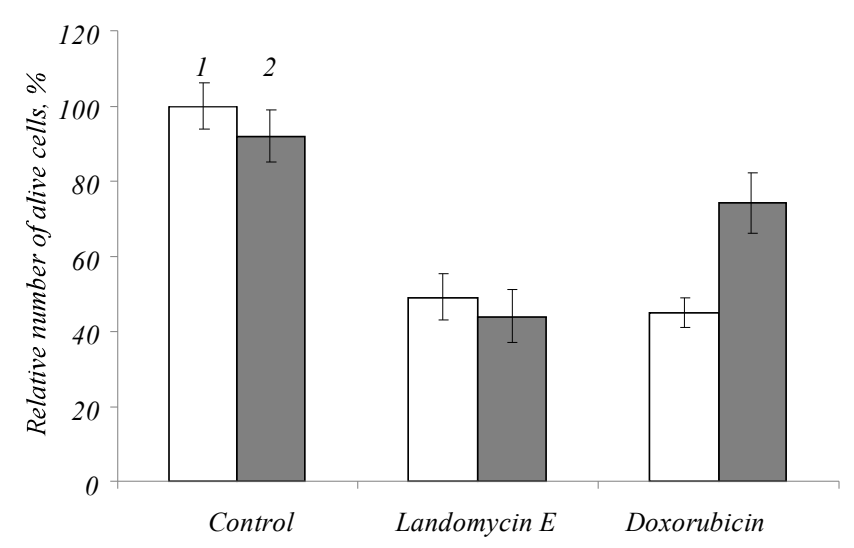

Fig. 6. Effect of broad caspase inhibitor z-VAD-fmk on survival of Jurkat T-leukemia cells under treatment with landomycin E and doxorubicin $(2 \mu \mathrm{g} / \mathrm{ml}, 24 \mathrm{~h}): 1$ - no z-VAD-fmk; $2-+100 \mu \mathrm{M} \mathrm{z}-\mathrm{VAD}-\mathrm{fmk}$

dependent process which is not blocked by NAC. Then caspase-10 can cleave caspase-7 (6 h) which activates mitochondria-signaling pathway accompanied by a release of AIF (6 h), ROS generation, and cleavage of PARP-1 and DFF45 (6 h). Since broad caspase inhibitor $\mathrm{z}$-VAD-fmk does not block apoptosis induced by LE even after $24 \mathrm{~h}$ treatment, we suggest that effector caspases play a supplementary role at late stages of LEinduced apoptosis, while AIF is a key effector protein that orchestrates apoptosis network upon LE action.

Conclusions. LE, despite lower cytotoxic activity comparing with Dx, induces more rapid development of apoptosis. This suggests different molecular mechanisms of the cytotoxic action of LE. The results of Western-blot analysis indicate that LE induces apoptosis of mixed type. At early stages of LE action, the initiator caspase-10 involved in the receptor-mediated apoptosis is important, while at later stages, AIF release from mitochondria takes place, and this leads to ROS generation and caspase-independent cleavage of DNA that is confirmed by caspase inhibition tests. Such dual LE action suggests that this antibiotic could be used as an effective anticancer drug of second line of defense. This predicts LE ability to overcome tumor refractoriness to treatment with anticancer drugs (e. g., doxorubicin, cisplatin, vincristin) killing cancer cells via classic caspase-dependent apoptotic mechanisms.

Acknowledgements. This work was partially supported by personal grants to R. Panchuk from WestUkrainian Biomedical Research Center (WUBMRC) in
2008-2010. The author also thanks prof. B. P. Matselyukh for providing Landomycin E, and prof. R. S. Stoika for valuable advices at conducting the research and preparing the manuscript.

\section{Р. Р. Панчук}

Сигнальні шляхи, залучені до індукції апоптозу новітнім ангуцикліновим антибіотиком ландоміцином Е в клітинах Т-лейкемії людини лінії Jurkat

Резюме

Мета. Дослідити молекулярні механізми дї̈ нового протипухлинного антибіотика ландоміщину Е (ЛЕ). Методи. Фарбування клітин анексином V, йодистим пропідієм, DAPI (4',6-діаміно-2-феніліндол), Вестерн-блот аналіз. Результати. Визначено, що ЛЕ (2 мкг/мл) індукує розщеплення білків PARP-1 (poly [ADP-ribose] polymerase 1) ma DFF45 (DNA Fragmentation Factor 45), залучених до репарації ДНК, вже через 6 год після додавання до клітинної культури. Це явище опосередковане активними сполуками кисню (АСК) і позитивно корелює з екстерналізацією фосфатидилхоліну на поверхні плазматичної мембрани (ранній маркер апоптозу). Розщеплення PARP-1 i DFF45 здійснюється активною каспазою-7 - ключовою ефекторною каспазою у ЛЕ-опосередкованому апоптозі в лейкемічних клітинах. Найранішньою подією у сигнальних шляхах апоптозу, спричиненого ЛЕ, виявилася активація ініціаторної прокаспази-10, причетної до реиептор-опосередкованого апоптозу. Показано, що ией прочес є АСК-незалежним. Нами також встановлено, що індукиія апоптозу ЛЕ супроводжується активацією апоптоз-індукуючого фактора (АIФ) в мітохондріях. Висновки. ЛЕ-індукований каскад апоптичних подій починається з активації ініціаторної каспази-10, щэо призводить до подальшої активації ефекторної каспази-7 та АІФ, який здатний індукувати каспазо-незалежний апоптоз за участі $A C K$.

Ключові слова: злоякісні клітини, ландоміцин Е, апоптоз, каспази, апоптоз-індукуючий фактор, активні сполуки кисню.

\section{Р. Р. Панчук}

Сигнальные пути, участвующие в индукции апоптоза новым ангуциклиновым антибиотиком ландомицином $\mathrm{E}$ в клетках Т-лейкемии человека линии Jurkat

Резюме

Цель. Исследовать молекулярные механизмы действия нового противоопухолевого антибиотика ландомицина Е (ЛЕ). Методы. Окрашивание клеток аннексином V, йодистым пропидием, DAPI (4',6-диамино-2-фенилиндол), Вестерн-блот анализ. Результаты. Определено, что ЛЕ (2 мкг/мл) индуцирует расщепление белков PARP-1 (poly [ADP-ribose] polymerase 1) и DFF45 (DNA Fragmentation Factor 45), причастных к репарачии ДНК, уже через 6 ч после добавления к клеточной культуре. Это явление опосредовано активныли соединениями кислорода (АCК) и положительно коррелирует с экстернализачией фосфатидилхолина на поверхности плазматической мембраны (ранний маркер апоптоза). Расщепление PARP-1 и DFF45 осуществляется активной каспазой-7 - ключевой эффекторной каспазой в 
ЛЕ-опосредованном апоптозе в лейкемических клетках. Наиболее ранним событием в сигнальных путях апоптоза, вызванного ЛЕ, оказалась активация инициаторной прокаспазы-10, участвующей в рецептор-опосредованном апоптозе. Показано, что этот процесс является АСК-независимым. Нами также установлено, что индукция апоптоза ЛЕ сопровождается активацией апоптоз-индуцирующего фактора (АИФ) в митохондриях. Выводы. ЛЕ-индуичированный каскад апоптических событий начинается с активации инициаторной каспазы-10, что приводит к дальнейшей активачии эффекторной каспазы-7 и АИФ, который способен индуцировать каспазо-независимыци апоптоз при участии активных форм кислорода.

Ключевые слова: злокачественные клетки, ландомицин Е, апоптоз, каспазы, апоптоз-индуцирующий фактор, активные соединения кислорода.

\section{REFERENCE}

1. Rohr J., Hertweck C. Type II PKS // Comprehensive natural products II: Chemistry and Biology / Eds L. Mander, H.-W. Liu.-Oxford: Elsevier, 2010.-Vol. 1.-P. 227-303.

2. Rohr J., Thiericke R. Angucycline group antibiotics // Nat. Prod. Rep.-1992.-9, N 2.-P. 103-137.

3. Krohn K., Rohr J. Angucyclines: Total syntheses, new structures and biosynthetic studies of an emerging new class of antibiotics // Top. Curr. Chem.-1997.-188.-P. 127-195.

4. Ostash I., Ostash B., Luzhetskyy A., Bechthold A., Walker S., Fedorenko $V$. Coordination of export and glycosylation of landomycins in Streptomyces cyanogenus S136 // FEMS Microbiol. Lett.-2008.-285, N 2.-P. 195-202.

5. Henkel T., Rohr J., Beale J.M., Schwenen L. Landomycins, new angucycline antibiotics from Streptomyces sp. I. Structural studies on landomycins A-D // J. Antibiot.-1990.-43, N 5.-P. 492503.

6. Luzhetskyy A., Zhu L., Gibson M., Fedoryshyn M., Durr C., Hofmann C., Hoffmeister D., Ostash B., Mattingly C., Adams V., Fedorenko V., Rohr J., Bechthold A. Generation of novel landomycins $\mathrm{M}$ and $\mathrm{O}$ through targeted gene disruption // Chembiochem.-2005.-6, N 4.-P. 675-678.

7. Shaaban K. A., Srinivasan S., Kumar R., Damodaran C., RohrJ. Landomycins P-W, cytotoxic angucyclines from Streptomyces cyanogenus S-136 // J Nat Prod.-2011.-74, N 1.-P. 2-11.

8. Crow R. T., Rosenbaum B., Smith R., Guo Y., Ramos K. S., Sulikowski G. A. Landomycin A inhibits DNA synthesis and G1/S cell cycle progression // Bioorg. Med. Chem. Lett.-1999.-9, N 12.-P. 1663-1666.

9. Depenbrock H., Bornschlegl S., Peter R., Rohr J., Schmid P., Schweighart P., Block T., Rastetter J., Hanauske A. R. Assessment of antitumor activity of landomycin A (NSC 6399187-A) // Ann. Hematol.-1996.-73 (Suppl. II).-A80/316.

10. Matselyukh B. P., Konovalova T. A., Polistchuk L. V., Bambura $O$. I. Sensitivity of streptomycetes producing polyketyde antibiotics to landomycine A and E // Microbiol. Zhur.-1998.60.-P. 31-36.

11. Korynevska A. V., Matselyukh B. P., Stoika R. S. In vitro study of landomycin E antitumor activity // Exp. Oncol.-2003.-25, N 2.P. 98-104.
12. Polistchuk L. V., Ganusevich P., Matselyukh B. P. The study of antitumor action of antibiotics produced by Streptomyces globisporus 1912 on Guerin's carcinoma // Microbiol. Zhur.1996.-58.-P. 55-58.

13. Panchuk R., Korynevska A., Ostash B., Osyp Y., Fedorenko V., Stoika R. Mechanisms of landomycin E action on mammalian cells // Visn. L'viv Univ. Biol. Ser.-2004.-35.-P. 54-59.

14. Korynevska A., Heffeter P., Matselyukh B., Elbling L., Micksche $M$., Stoika R., Berger $W$. Mechanisms underlying the anticancer activities of the angucycline landomycin E// Biochem. Pharmacol.-2007.-74, N 12.-P. 1713-1726.

15. Panchuk R. R., Boiko N. M., Lootsik M. D., Stoika R. S. Changes in signaling pathways of cell proliferation and apoptosis during NK/Ly lymphoma aging // Cell Biol. Int.-2008.-32, N 9.P. 1057-1063.

16. Vermes I., Haanen C., Steffens-Nakken H., Reutellingsperger C. A novel assay for apoptosis - flow cytometric detection of phosphatidylserine expression on early apoptotic cells using fluorescein labelled Annexin V // J. Immunol. Meth.-1995.-184 N 1.P. 39-51.

17. Nitiss $J$. Targeting DNA topoisomerase II in cancer chemotherapy // Nat. Rev Cancer.-2009.-9, N 5.-P. 338-350.

18. Tsang W. P., Chau S. P., Kong S. K., Fung K. P., Kwok T. T. Reactive oxygen species mediate doxorubicin induced p53-independent apoptosis // Life Sci.-2003.-73 N 16.-P. 2047-2058.

19. Gewirtz D. A. A critical evaluation of the mechanisms of action proposed for the antitumor effects of the anthracycline antibiotics adriamycin and daunorubicin // Biochem. Pharmacol.1999.-57, N 7.-P. 727-741.

20. Manda G., Nechifor M., Neagu T-M. Reactive oxygen species, cancer and anti-cancer therapies // Curr. Chem. Biol.-2009.-3, N 1.-P. 22-46.

21. Verbrugge I., Maas C., Heijkoop M., Verheij M., Borst J. Radiation and anticancer drugs can facilitate mitochondrial bypass by CD95/Fas via c-FLIP downregulation // Cell Death Differ. 2010.-17, N 3.-P. 551-561.

22. Kim R., Tanabe K., Uchida Y., Emi M., Inoue H., Toge T. Current status of the molecular mechanisms of anticancer drug-induced apoptosis. The contribution of molecular-level analysis to cancer chemotherapy // Cancer Chemother. Pharmacol.-2002.50, N 5.-P. 343-352.

23. Constantinou C., Papas K. A., Constantinou A. I. Caspase-independent pathways of programmed cell death: the unraveling of new targets of cancer therapy? // Curr. Cancer Drug Targets.2009.-9, N 6.-P. 717-728.

24. Susin S.A., Lorenzo H. K., Zamzami N., Marzo I., Snow B. E., Brothers G. M., Mangion J., Jacotot E., Costantini P., Loeffler M., Larochette N., Goodlett D. R., Aebersold R., Siderovski D. P., Penninger J. M., Kroemer G. Molecular characterization of mitochondrial apoptosis-inducing factor // Nature.-1999.-397, N 6718.-P. 441-446.

25. Joza N., Pospisilik J.A., Hangen E., Hanada T., Modjtahedi N., Penninger J.M., Kroemer G. AIF: not just an apoptosis-inducing factor // Ann. N. Y. Acad. Sci.-2009.-1171.-P. 2-11.

26. Modjtahedi N., Giordanetto F., Madeo F., Kroemer G. Apoptosis-inducing factor: vital and lethal // Trends Cell. Biol.-2006.16 N 5.-P. 264-272. 